\title{
EFEKTIVITAS PEMBELAJARAN INVESTIGASI KELOMPOK BERBANTUAN PETA KONSEP TERHADAP PEMAHAMAN KONSEP MATEMATIS SISWA
}

\author{
HENDRA YULIANTO \\ Universitas Negeri Semarang, Jl. Kelud Utara III, Semarang, Indonesia \\ hendraokta1993@students.unnes.ac.id
}

First Received: 03-03-2020; Accepted: 07-10-2020

\begin{abstract}
Abstrak
Tujuan penelitian ini adalah menganalisis keefektifan pembelajaran investigasi kelompok berbantuan peta konsep terhadap pemahaman konsep matematis siswa. Jenis penelitian ini adalah penelitian kuantitatif dengan metode eksperimen semu (quasi experiment). Pada kelas eksperimen siswa diajarkan dengan pembelajaran investigasi kelompok berbantuan peta konsep dan pada kelas kontrol siswa diajarkan dengan pembelajaran ekspositori. Populasi dalam penelitian ini adalah siswa kelas XI MIPA SMA Negeri 1 Ngabang Tahun Ajaran 2019/2020. Pemilihan sampel menggunakan teknik cluster random sampling, diperoleh kelas XI MIPA A sebagai kelas eksperimen dan kelas XI MIPA C sebagai kelas kontrol. Analisis data akhir menggunakan one sample t-test, uji proporsi pihak kanan, dan uji rata-rata pihak kanan. Hasil penelitian menunjukkan bahwa ketuntasan individu pemahaman konsep matematis kelas eksperimen memenuhi KKM dan secara klasikal mencapai $70 \%$. Kemudian pemahaman konsep matematis siswa pada kelas eksperimen lebih baik daripada kelas kontrol. Berdasarkan hasil penelitian disimpulkan bahwa pembelajaran investigasi kelompok berbantuan peta konsep efektif terhadap pemahaman konsep matematis siswa.
\end{abstract}

Kata kunci: Investigasi kelompok; peta konsep; pemahaman konsep matematis

\section{EFFECTIVENESS OF LEARNING GROUP INVESTIGATION ASSISTED WITH CONCEPT MAP OF UNDERSTANDING STUDENT MATHEMATIC CONCEPTS}

\begin{abstract}
The purpose of this study was to analyze the effectiveness of group investigative learning assisted by concept maps on students' understanding of mathematical concepts. This type of research is a quantitative study with a quasi-experimental method. In the experimental class, students were taught by learning group investigations assisted by concept maps and in the control class students were taught by using expository learning. The population in this study were students of class XI MIPA at SMA Negeri 1 Ngabang for the 2019/2020 academic year. The sample selection using cluster random sampling technique, obtained class XI MIPA A as the experimental class and class XI MIPA C as the control class. The final data analysis
\end{abstract}


used one sample t-test, right side proportion test, and right side average test. The results showed that the individual completeness in understanding the mathematical concepts of the experimental class fulfilled the KKM and classically reached $70 \%$. Then the students' understanding of mathematical concepts in the experimental class was better than the control class. Based on the results of the study, it was concluded that group investigation learning assisted by concept maps was effective in understanding students' mathematical concepts.

Keywords: Group Investigation; concept map; understanding mathematical concepts

\section{PENDAHULUAN}

Pemahaman konsep menurut Malatjie \& Machaba (2019) mengacu pada pemahaman konseptual sebagai koneksi ide yang tidak terputus satu sama lain. Implikasinya seorang siswa memiliki pemahaman konsep ketika dia mampu menjelaskan, menggambarkan, dan menerapkan konsep yang sama dengan cara dan situasi yang berbeda. Hal ini mengacu pada situasi dimana siswa mampu memahami dan mengintegrasikan setiap konsep sehingga terbentuk pola dan hubungan yang jelas tentang konsep tersebut. Lebih lanjut Arifah \& Saefudin (2017) mengungkapkan bahwa siswa yang mempunyai pemahaman konsep yang baik apabila mampu mendefinisikan konsep, mengidentifikasi, dan memberikan contoh atau bukan contoh dari konsep serta mampu mengambangkan koneksi antar ide sehingga membentuk pemahaman menyeluruh tentang konsep yang dipelajari.

Matematika sebagai ilmu yang erat kaitannya dengan permasalahan sehari-hari memerlukan pengetahuan dasar berupa pemahaman konsep sebagai landasan berpikir. Andamon \& Tan (2018) mengungkapkan bahwa pemahaman konsep matematis merupakan pengetahuan yang melibatkan pemahaman menyeluruh tentang dasar dan landasan konsep di balik alogaritma dalam matematika. Sifat konsep dalam matematika saling berkaitan dan menjadi prasyarat bagi konsep lain. Sehingga proses membangun konsep matematis harus dimulai dari konsep dasar sebelum melanjutkan pada konsep selanjutnya. Suarsana, Widiasih, \& Suparta (2018) mengungkapkan bahwa pemahaman konsep berperan penting dalam membangun kerangka kognitif siswa dan meningkatkan pemahaman siswa tentang materi pelajaran. Menurut Malatjie \& Machaba (2019) siswa yang mempunyai pemahaman konsep matematis yang baik mampu menjelaskan, menggambarkan, dan menerapkan konsep yang sama dengan cara dan situasi yang berbeda.

Berdasarkan pengamatan siswa kelas XI MIPA di SMAN 1 Ngabang menunjukkan bahwa pemahaman konsep matematis siswa masih kurang. Siswa belum mampu menjelaskan dan menerapkan konsep yang dipelajari pada suatu permasalahan. Kemudian koneksi antar 
konsep juga masih kurang, hal tersebut terlihat dari proses pengaitan dan pengintegrasian beberapa ide matematika belum menghasilkan pola dan hubungan yang jelas. Akibatnya siswa kebingungan langkah mana sebaiknya dipakai dan bagaimana penggunaanya untuk menyelesaikan permasalahan yang diberikan. Sehingga hal tersebut menunjukkan bahwa pemahaman konsep matematis siswa masih belum optimal.

Kemudian hasil pengamatan terhadap pembelajaran yang diterapkan guru masih menggunakan pembelajaran konvensional yaitu pembelajaran ekspositori. Sebagaimana yang diungkapkan oleh Shadiq (2009) bahwa pembelajaran ekspositori tidak memungkinkan siswa berpartisipasi secara penuh, karena kegiatan pembelajaran lebih menekankan siswa untuk mengingat atau menghafal dan kurang pada pemahaman. Pemahaman konsep dapat terjadi jika siswa dilibatkan secara penuh dalam pembelajaran untuk memahami dan mendalami pengetahuan dasar sebagai landasan pemahaman konsep. Pembelajaran yang diyakini dapat mengoptimalkan pemahaman konsep matematis siswa yaitu pembelajaran investigasi kelompok.

Menurut Santoso (2019) pembelajaran investigasi kelompok merupakan pembelajaran kooperatif yang memungkinkan siswa untuk melakukan penyelidikan terhadap suatu topik pembelajaran. Kegiatan penyelidikan yang dilakukan meliputi investigasi, interaksi, dan penafsiran. Kegiatan investigasi dilakukan dengan membangun pengetahuan siswa melalui masalah yang menantang dan rumit kepada siswa. Kegiatan interaksi dilakukan dengan memberikan dorongan untuk mengembangkan gagasan satu sama lain. Kemudian kegiatan penafsiran dilakukan dengan menggabungkan beberapa gagasan yang diperoleh sehingga menghasilkan pengetahuan baru yang komprehensif.

Hasil penelitian Parinduri, Sirait, \& Sani (2017) menunjukkan bahwa pembelajaran investigasi kelompok dapat meningkatkan pemahaman konseptual siswa terhadap materi yang diajarkan. Hasil tersebut diperoleh karena siswa dalam pembelajaran investigasi kelompok diberikan tugas-tugas yang spesifik dan menantang untuk meningkatkan keingintahuan dan mengembangkan gagasan mereka dengan sudut pandang yang berbeda. Kemudian siswa juga dilibatkan secara langsung dalam pembelajaran. Sebagaimana yang diungkapkan oleh Gilmore dkk, (2017) bahwa melibatkan siswa secara langsung dalam pembelajaran untuk memilih dan menerapkan konsep dapat meningkatkan pemahaman konsep siswa.

Pemahaman konsep matematis siswa juga dapat ditingkatkan dengan menggunakan peta konsep. Hasil penelitian Junedi \& Sari (2019) menunjukkan bahwa peta konsep dapat meningkatkan pemahaman konsep matematis siswa. Menurut Malatjie \& Machaba (2019) peta 
konsep dapat menggambarkan hubungan antar konsep secara terstruktur. Keterkaitan antar konsep dihubungkan dengan garis yang menunjukkan bagaimana konsep tersebut saling berkaitan. Penggunaan peta konsep dalam pembelajaran memudahkan siswa menggunakan dan memilih prosedur tertentu serta mengaplikasikannya sebagai solusi permasalahan matematika.

Berdasarkan uraian di atas diperoleh bahwa, pembelajaran matematika memerlukan pengetahuan dasar berupa pemahaman konsep. Sehingga dengan dasar tersebut peneliti akan mengembangkan kemampuan pemahaman konsep matematis siswa melalui pembelajaran investigasi kelompok berbantuan peta konsep. Tujuan dari penelitian ini adalah untuk menganalisis keefektifan pembelajaran investigasi kelompok berbantuan peta konsep terhadap pemahaman konsep matematis siswa. Keefektifan tersebut ditunjukkan melalui tiga hal yaitu: (1) apakah pemahaman konsep matematis siswa pada pembelajaran investigasi kelompok berbantuan peta konsep memenuhi KKM? (2) apakah pemahaman konsep matematis siswa yang memenuhi KKM pada pembelajaran investigasi kelompok berbantuan peta konsep mencapai 70\% (3) apakah pemahaman konsep matematis siswa pada pembelajaran investigasi kelompok berbantuan peta konsep lebih baik daripada pembelajaran ekspositori?

\section{METODE PENELITIAN}

Penelitian ini merupakan penelitian kuantitatif dengan metode eksperimen semu (quasi experiment) karena peneliti tidak dapat mengontrol variabel-variabel lain yang dapat mempengaruhi penelitian. Siswa pada kelas eksperimen mendapat pembelajaran investigasi kelompok berbantuan peta konsep dan pada kelas kontrol mendapat pembelajaran ekspositori. Pemilihan sampel menggunakan teknik cluster random sampling. Menurut Sukardi (2015) teknik pemilihan sampel ini bukan didasarkan pada individu, tetapi pada kelompok, daerah, atau kelompok subjek yang secara alami berkumpul bersama.

Kegiatan penelitian dimulai dengan tahap persiapan perangkat penelitian yang meliputi silabus, Rencana Pelaksanaan Pembelajaran (RPP), Lembar Kerja Kelompok (LKK), dan tes pemahaman konsep matematis siswa. Perangkat penelitian yang telah disusun divalidasi terlebih dahulu oleh validator ahli. Kegiatan validasi digunakan untuk menguji kelayakan instrumen berupa kejelasan tujuan pengukuran, kesesuaian butir pertanyaan/pernyataan, penggunaan bahasa, dan kejelasan petunjuk penggunaan. Kemudian dilanjutkan tahap pelaksanaan penelitian dengan menerapkan pembelajaran investigasi kelompok berbantuan peta konsep di kelas eksperimen dan pembelajaran ekspositori di kelas kontrol. 
Pengumpulan data meliputi metode dokumentasi dan metode tes. Metode dokumentasi digunakan untuk mendapatkan data tentang sekolah, siswa, perangkat pembelajaran di sekolah, hasil catatan lapangan, hasil wawancara, dan foto-foto kegiatan penelitian. Metode tes yang digunakan adalah soal uraian tes pemahaman konsep matematis. Soal tes yang diberikan merupakan tes yang telah diuji coba tingkat kesahihan dan keabsahannya, yang meliputi validitas, reliabilitas, taraf kesukaran, dan daya pembeda butir soal.

Analisis data akhir menggunakan data hasil pemahaman konsep matematis siswa yang diperoleh pada kelas eksperimen dan kelas kontrol. Analisis data akhir digunakan untuk menguji kebenaran hipotesis. Data akhir yang akan dianalisis merupakan data yang telah memenuhi prasyarat uji hipotesis yang meliputi uji normalitas dan homogenitas. Uji normalitas menggunakan uji kolmogrov smirnov dengan taraf signifikan 5\% sedangkan untuk uji homogenitas menggunakan levene statistic test dengan taraf signifikan 5\%. Setelah uji prasyarat terpenuhi, maka dapat dilakukan uji hipotesis. Uji hipotesisi 1 menggunakan one sample t-test untuk menguji apakah pemahaman konsep matematis siswa pada kelas eksperimen memenuhi KKM yaitu 65 atau belum. Kemudian uji hipotesis 2 menggunakan uji proporsi pihak kanan untuk menguji apakah ketuntasan individu pada kelas eksperimen mencapai $70 \%$ atau belum. Selanjutnya uji hipotesis 3 menggunakan uji rata-rata pihak kanan untuk menguji pemahaman konsep matematis mana yang lebih baik antara kelas eksperimen dan kelas kontrol.

\section{HASIL DAN PEMBAHASAN}

Populasi dalam penelitian ini adalah siswa kelas XI MIPA SMA Negeri 1 Ngabang Tahun Ajaran 2019/2020 sebanyak 154 siswa yang terbagi dalam empat kelas. Berdasarkan hasil pemilihan sampel diperoleh kelas XI MIPA A sebagai kelas eksperimen dan kelas XI MIPA C sebagai kelas kontrol. Kemudian materi yang dipilih dalam penelitian ini adalah irisan kerucut. Hasil uji normalitas menggunakan uji kolmogrov smirnov pada kelas eksperimen diperoleh nilai signifikansi $\alpha=0,453>0,05$ sehingga data berdistribusi normal, sedangkan pada kelas kontrol diperoleh nilai signifikansi $\alpha=0,452>0,05$ sehingga data berdistribusi normal. Kemudian hasil uji homogenitas menggunaan levene statistic test diperoleh nilai signifikansi $\alpha=0,650>0,05$ sehingga data homogen.

Hasil penelitian dan pembahasan merupakan hasil tes pemahaman konsep matematis siswa di kelas eksperimen dan kelas kontrol yang telah mendapatkan perlakuan berbeda. 
Perolehan nilai tes pemahaman konsep matematis siswa secara lengkap disajikan pada Tabel 1 berikut.

Tabel 1. Nilai Tes Pemahaman Konsep Matematis Siswa

\begin{tabular}{lcc}
\hline \multicolumn{1}{c}{ Kriteria } & Kelas Eksperimen & Kelas Kontrol \\
\hline Banyak siswa & 38 & 37 \\
Nilai tertinggi & 88 & 84 \\
Nilai terendah & 52 & 52 \\
Rata-rata & 73,37 & 69,30 \\
Banyak siswa yang tuntas & 32 & 26 \\
Persentase ketuntasan & $81,6 \%$ & $70,2 \%$ \\
\hline
\end{tabular}

Hasil uji hipotesis 1 menggunakan one sample $t$-test, diperoleh $\mathrm{t}$ hitung $=5,7$ dan $\mathrm{t}$ tabel $=1,7$ karena $\mathrm{t}$ hitung $>\mathrm{t}$ tabel maka $H_{0}$ ditolak, artinya pemahaman konsep matematis siswa pada kelas eksperimen memenuhi KKM yaitu 65. Sehingga dapat disimpulkan pemahaman konsep matematis siswa pada pembelajaran investigasi kelompok berbantuan peta konsep memenuhi KKM yaitu 65 .

Hasil uji hipotesis 2 menggunakan uji proporsi pihak kanan. Secara deskriptif banyaknya siswa yang memenuhi KKM pada kelas eksperimen adalah 32 siswa, artinya persentase ketuntasan belajar dalam aspek pemahaman konsep matematis adalah 81,6\%. Kemudian secara statistik menggunakan uji ketuntasan klasikal diperoleh $z$ hitung $=1,91$ dan $z$ tabel =1,64 karena $z$ hitung $>\mathrm{z}$ tabel maka $H_{0}$ ditolak, artinya ketuntasan individu pada kelas eksperimen mencapai 70\%. sehingga dapat disimpulkan pemahaman konsep matematis siswa yang memenuhi KKM pada pembelajaran investigasi kelompok berbantuan peta konsep mencapai $70 \%$.

Hasil uji hipotesis 3 menggunakan uji rata-rata pihak kanan. Secara deskriptif diperoleh rata-rata pemahaman konsep matematis siswa pada pembelajaran investigasi berbantuan peta konsep kelompok 73,37 lebih dari rata-rata siswa pada pembelajaran ekspositori 69,30. Kemudian secara statistik diperoleh $\mathrm{t}$ hitung $=2,02$ dan $t$ tabel $=1,67$ karena $t$ hitung $>t$ tabel maka $H_{0}$ ditolak, artinya pemahaman konsep matematis siswa pada kelas eksperimen lebih baik daripada kelas kontrol. sehingga dapat disimpulkan pemahaman konsep matematis siswa pada pembelajaran investigasi kelompok berbantuan peta konsep lebih baik daripada pembelajaran ekspositori.

Berdasarkan uji hipotesis yang telah dilakukan diperoleh hasil bahwa pembelajaran investigasi kelompok berbantuan peta konsep efektif terhadap pemahaman konsep matematis siswa. Efektivitas tersebut terlihat dari pemahaman konsep matematis siswa pada pembelajaran investigasi kelompok berbantuan peta konsep memenuhi KKM mencapai 70\% dan lebih tinggi dibandingkan dengan pembelajaran ekspositori. Kemudian perolehan rata-rata pemahaman 
konsep matematis siswa pada pembelajaran investigasi kelompok berbantuan peta konsep lebih tinggi daripada pembelajaran ekspositori. Hasil tersebut sesuai dengan hasil penelitian Kharimah \& Muhsetyo (2010) bahwa pembelajaran investigasi kelompok dengan media peta konsep dapat menghindari kesalahan konseptual siswa dan meningkatkan hasil belajar siswa. Kemudian hasil penelitian Sitorus, M.S (2019) menunjukkan bahwa terdapat pengaruh yang signfikan penggunaan media peta konsep terhadap pemahaman konsep matematis siswa.

Kefektifan pembelajaran investigasi kelompok berbantuan peta konsep tidak terlepas dari peran masing-masing komponennya. Pembelajaran investigasi kelompok menekankan pada pendalaman konsep melalui kegiatan penyelidikan secara sistematis. Sehingga siswa mampu membangun pemahaman konsep yang mendalam dan menyeluruh. Suprijono (2014) mengungkapkan bahwa siswa pada pembelajaran investigasi kelompok bekerja berdasarkan metode investigasi yang telah mereka rumuskan, sehingga memungkinkan untuk bekerja secara sistematis. Ketika siswa melakukan kegiatan penyelidikan, konsep akan diperoleh menjadi lebih jelas sehingga siswa dapat menghubungkan dan mengampikasikannya pada permasalahan yang diberikan.

Kemudian penggunaan peta konsep dalam pembelajaran membantu siswa menghubungkan dan memperjelas bagaimana pola dan keterkaitan konsep tersebut. Muhsetyo (2008) mengungkapkan bahwa penggunaan peta konsep dalam pembelajaran memungkinkan hubungan antar konsep menjadi lebih jelas dan keseluruhan konsep teridentifikasi. Hal tersebut berimplikasi pada kemampuan siswa menghungkan beberapa konsep terkait dan membentuk pola hubungan yang jelas antara konsep yang lama dan yang baru dipelajari. Ketika pola hubungan menjadi jelas maka akan membantu siswa menemukan solusi permasalahan meskipun masalah yang diberikan situasinya berbeda.

\section{SIMPULAN}

Berdasarkan pembahasan yang dilakukan diperoleh bahwa pembelajaran investigasi kelompok berbantuan peta konsep selain membantu siswa mendalami konsep dan prosedur dalam matematika juga membantu siswa memahami keterkaitan antar konsep. Berbeda dengan pembelajaran ekspositori, siswa terlihat kurang memahami bagaimana penggunaan konsep dan prosedur yang telah diajarkan sehingga kesulitan dalam menyelesaian permasalahan yang diberikan. Siswa hanya terbiasa menghafal konsep tanpa memahami bagaimana penggunaan dan kaitannya dengan konsep lainnya. Dengan demikian, dapat disimpulkan bahwa pembelajaran investigasi kelompok berbantuan peta konsep efektif terhadap pemahaman 
konsep matematis siswa. Keefektifan tersebut ditunjukkan melalui tiga hal, yatu: (1) pemahaman konsep matematis siswa pada pembelajaran investigasi kelompok memenuhi $\mathrm{KKM}$; (2) pemahaman konsep matematis siswa yang memenuhi KKM pada pembelajaran investigasi kelompok berbantuan peta konsep mencapai 70\%; (3) pemahaman konsep matematis siswa pada pembelajaran investigasi kelompok berbantuan peta konsep lebih baik daripada pembelajaran ekspositori.

\section{DAFTAR PUSTAKA}

Andamon, J. C., \& Tan, D. A. (2018). Conceptual understanding, attitude and performance in mathematics of Grade 7 Students. International Journal of Scientific and Technology Research, 7(8), 96-105.

Arifah, U., \& Saefudin, A. A. (2017). Menumbuhkambangkan Kemampuan Pemahaman Konsep Matematika dengan Menggunakan Model Pembelajaran Guided Discovery. UNION: Jurnal Ilmiah Pendidikan Matematika, 5(3), 263-272.

Gilmore, C., Keeble, S., Richardson, S., \& Cragg, L. (2017). The interaction of procedural skill, conceptual understanding and working memory in early mathematics achievement. Journal of Numerical Cognition, 3(2), 400-416.

Junedi, B., \& Sari, P. (2019). Penggunaan Model Pembelajaran Concept Mapping Terhadap Pemahaman Konsep Matematika Siswa Kelas VII. Jurnal Saintika Unpam : Jurnal Sains Dan Matematika Unpam, 1(2), 222.

Kharimah, U., \& Muhsetyo, G. (2010). Penggunaan Media Peta Untuk Memahamkan Materi Perbandingan Melalui Pembelajaran Kooperatif Tipe Grup Investigasi Pada Siswa Kelas VII-A SMP Negeri 2 Jetis Kabupaten Mojokerto. Jurnal Universitas Negeri Malang, 113.

Malatjie, F., \& Machaba, F. (2019). Exploring mathematics learners' conceptual understanding of coordinates and transformation geometry through concept mapping. Eurasia Journal of Mathematics, Science and Technology Education, 15(12), 1-16.

Muhsetyo, G. (2008). Pembelajaran Matematika SD. Universitas Terbuka.

Parinduri, S. H., Sirait, M., \& Sani, R. A. (2017). The Effect of Cooperative Learning Model Type Group Investigation for Student's Conceptual Knowledge and Science Process Skills. IOSR Journal of Research \& Method in Education, 7(October), 49-54.

Santoso, A. (2019). Efforts To Train the Character of Students By Using the Cooperative Learning Model Type Gi (Group Investigation) in Science Learning. Science Education and Application Journal, 1(1), 25. 
Shadiq, F. (2009). MODEL-MODEL PEMBELAJARAN MATEMATIKA SMP. PPPPTK Matematika.

Sitorus, M. S. (2019). Pengaruh Model Pembelajaran Pencapaian Konsep Berbantu Media Peta Konsep Terhadap Kemampuan Pemahaman Matematis dan Komunikasi Matematika Peserta Didik pada Materi Perbandingan di Kelas VII SMP Negeri 1 Balige Tahun Pelajaran 2018/2019.

Suarsana, M., Widiasih, N. P. S., \& Suparta, N. (2018). The effect of brain based learning on second grade junior students' mathematics conceptual understanding on polyhedron. Journal on Mathematics Education, 9(1), 145-155.

Sukardi. (2015). Metodologi Penelitian Pendidikan Kompetensi dan Praktiknya. PT Bumi Aksara.

Suprijono, A. (2014). Cooperative Learning Teori dan Aplikasi PAIKEM. Pustaka Pelajar. 